NASA Technical Memorandum 105240

AIAA-91-3629

\title{
The NASA CSTI High Capacity Power Program
}

Jerry M. Winter

Lewis Research Center

Cleveland, Ohio

Prepared for the

Conference on Advanced Space Exploration Initiative Technologies cosponsored by AIAA, NASA, and OAI

Cleveland, Ohio, September 4-6, 1991 


\section{DISCLAIMER}

This report was prepared as an account of work sponsored by an agency of the United States Government. Neither the United States Government nor any agency Thereof, nor any of their employees, makes any warranty, express or implied, or assumes any legal liability or responsibility for the accuracy, completeness, or usefulness of any information, apparatus, product, or process disclosed, or represents that its use would not infringe privately owned rights. Reference herein to any specific commercial product, process, or service by trade name, trademark, manufacturer, or otherwise does not necessarily constitute or imply its endorsement, recommendation, or favoring by the United States Government or any agency thereof. The views and opinions of authors expressed herein do not necessarily state or reflect those of the United States Government or any agency thereof. 


\section{DISCLAIMER}

Portions of this document may be illegible in electronic image products. Images are produced from the best available original document. 


\section{DISCLAIMER}

This report was prepared as an account of work sponsored by an agency of the United States Government. Neither the United States Government nor any agency thereof, nor any of their employees, makes any warranty, express or implied, or assumes any legal liability or responsibility for the accuracy, completeness, or usefulness of any information, apparatus, product, or process disclosed, or represents that its use would not infringe privately owned rights. Reference herein to any specific commercial product, process, or service by trade name, trademark, manufacturer, or otherwise does not necessarily constitute or imply its endorsement, recommendation, or favoring by the United States Government or any agency thereof. The views and opinions of authors expressed herein do not necessarily state or reflect those of the United States Government or any agency thereof. 


\title{
THE NASA CSTI HIGH CAPACITY POWER PROGRAM
}

\author{
Jerry M. Winter \\ National Aeronautics and Space Administration \\ Lewis Research Center \\ Cleveland, Ohio 44135
}

\section{Abstract}

The SP-100 program was established in 1983 by DOD, DOE, and NASA as a joint program to develop the technology necessary for space nuclear power systems for military and civil applications.

During 1986 and 1987, the NASA Advanced Technology Program was responsible for maintaining the momentum of promising technology advancement efforts started during Phase I of SP-100 and to strengthen, in key areas, the chances for successful development and growth capability of space nuclear reactor power systems for future space applications.

In 1988, the NASA Advanced Technology Program was incorporated into NASA's new Civil Space Technology Initiative (CSTI). The CSTI program was established to provide the foundation for technology development in automation and robotics, information, propulsion, and power. The CSTI High Capacity Power Program builds on the technology efforts of the SP-100 program, incorporates the previous NASA advanced technology project, and provides a bridge to the NASA exploration technology programs.

The elements of CSTI high capacity power development include conversion systems - Stirling and thermoelectric, thermal management, power management, system diagnostics, and environmental interactions. Technology advancement in all areas, including materials, is required to provide the growth capability, high reliability and 7 to 10 years lifetime demanded for future space nuclear power systems. The overall program will develop and demonstrate the technology base required to provide a wide range of modular power systems while minimizing the impact of day/night operation as well as attitudes and distance from the Sun.

Significant accomplishments in all of the program elements will be discussed, along with revised goals and project timelines recently developed.

\section{Introduction}

The CSTI program, conceived by NASA's Office of Aeronautics and Space Technology as a first step in the revitalization of the U. S. civil space technology base, emphasizes technology developments considered essential for reliable and efficient access to and operations in low Earth orbit, as well as for support of advanced scientific space mission operations. The goal of the CSTI program is to produce a validated space technology base in selected areas. Exploiting progress already made in NASA's Space Research and Technology program, CSTI is directed at specific technology advances in (1) transportation, (2) operations, and (3) science. The High Capacity Power Program Element is one of several space technologies considered essential to successful accomplishment of potential future civil space mission objectives.

A wide range of potential future civil space missions have been identified which could be enabled or substantially enhanced by the use of nuclear reactor power and propulsion. The identified power requirements can range from tens of kilowatts of electrical power required for support of robotic deep-space science missions, to the many hundreds of kilowatts or megawatts of electrical power required to support sustained human lunar and planetary surface operations as well as the very high powered nuclear propulsion systems that would be needed for round-trip crew transfer and large-scale planetary cargo options.

The CSTI High Capacity Power (HCP) Program element complements the ongoing Tri-Agency (DOD/DOE/NASA) SP-100 program, which is directed toward the development and validation of technology for a versatile space nuclear reactor power system with the capability to generate tens to hundreds of kilowatts of electrical power for at least 7 years at full power. The HCP program is aimed at identifying and providing options for achieving significantly higher performance and system growth potential, sizably reduced mass, and longer lifetimes 
at acceptable systems reliability for civil space applications. The objective of the HCP program is to develop the advanced technology for improved static and dynamic conversion systems, which when coupled with the nuclear reactor technology being developed in the SP-100 program, will meet civil space program goals. The systems benefits accruing from the HCP program are illustrated in Fig. 1. The SP-100 reactor system using thermoelectrics to produce $100 \mathrm{~kW}$ of power, is itself a significant advance in size and power density at $22 \mathrm{~W} / \mathrm{kg}$. NASA's current nuclear power systems, radioisotope thermoelectric generators, are long lived and reliable, but are restricted to power on the order of $1 \mathrm{kWe}$ by cost and mass considerations ( $5 \mathrm{~W} / \mathrm{kg}$ ). Advanced thermoelectrics can enhance both RTG's and SP-100 performance-to $27 \mathrm{~W} / \mathrm{kg}$ in the CSTI HCP program, and beyond in the base R\&T effort underway at JPL. Stirling power conversion, coupled to the SP-100 heat source, can advance power and power density in two technology steps, 1050 and $1300 \mathrm{~K}$, as illustrated in Fig. 1. The baseline CSTI program will develop the $1050 \mathrm{~K}$ superalloy Stirling space technology, while the Exploration Technology Program, scheduled for initiation in 1993, will carry on the development required, to reach the $1300 \mathrm{~K}$ refractory Stirling goal in 1999, based upon the technology developed earlier at $1050 \mathrm{~K}$. Stirling/nuclear power capability will enable applications such as the lunar base shown in Fig. 2, presently envisioned as requiring $550 \mathrm{kWe}$. Reference 1 presents the details of the design illustrated in Fig. 2. Other possible applications for Stirling space power in the multihundred kilowatt range include electric propulsion power for science and unmanned cargo missions to the outer planets, power for air and ocean radar traffic control systems, high power communication platforms, Earth observing platforms, and in-space materials processing facilities. Reference 2 provides a description of potential future civil space missions that could be enabled or substantially enhanced by the use of nuclear reactor power.

\section{Project Management}

The elements of CSTI HCP development include Stirling and thermoelectric conversion systems, thermal management, power management, system diagnostics and environmental interactions. Technology advancements in all areas, including materials, is required to meet the performance goals of Fig. 1 and to attain the high reliability over the
7 to 10 years lifetime demanded for future space nuclear power systems.

The funding planned for the baseline HCP project is listed by element in Table 1. Including prior years, total funding is about $\$ 61$ million. The major milestones and activities covered by this funding are shown on Fig. 3. The project culminates in a $1050 \mathrm{~K}$ Stirling system test in 1996, demonstrating all the relevant power conversion elements needed to produce electrical power from the SP-100 reactor heat source.

The project personnel level during FY91 is about 50 civil servants and 16 support service contractors at NASA Lewis plus 2-1/2 full time staff members at JPL.

The High Capacity Power Project has undergone significant changes since the IECEC paper given in 1989 (Ref. 3). Funding has been extended for 2 years (1995 and 1996), a $1050 \mathrm{~K}$ Stirling system test has been added, and the thermoelectric development is scheduled to be halted in FY94, after a $Z=1.0 \times 10^{-3} \mathrm{~K}^{-1}$ has been developed and the $Z=0.85 \times 10^{-3} \mathrm{~K}^{-1}$ has been carried through the multicouple demonstration phase. Advancing thermoelectric figure of merit $(Z)$ beyond 1.0 will be funded from other sources. The $1300 \mathrm{~K}$ Stirling system demonstration, scheduled for 1999, will be funded under the Exploration Technology Program, now scheduled to start in FY93.

\section{Stirling Power Conversion}

The $1050 \mathrm{~K}$ superalloy Stirling power converter development is proceeding as outlined on Fig. 4. Results of the most recent $650 \mathrm{~K}$ space power research engine (SPRE) development at NASA Lewis and $\mathrm{MTI}$ are given in Ref. 4. The component test power converter (CTPC) is intended to develop the $525 \mathrm{~K}$ cold end technology and the $1050 \mathrm{~K}$ hot end technology at the $12.5 \mathrm{kWe}$ size. The $25 \mathrm{kWe}$ $1050 \mathrm{~K}$, single cylinder superalloy space Stirling power converter will be tested in FY93, improved during FY94 and 95, then proven in a system test during FY96. Elements of the system to be included are given in the highlighted section of the nuclear Stirling diagram of Fig. 5 .

The most recent results are the successful motoring of the CTPC at temperatures up to $400 \mathrm{~K}$ with internally pumped gas bearings over the full 
operating range. Figure 6 shows the CTPC cold end hardware. The Stirling contract effort at MTI is supported by a wide range of NASA Lewis in-house testing as well as University grants and materials development.

\section{Thermoelectronics}

The Advanced Thermoelectric Project being carried out at JPL has been significantly changed by results obtained recently. The n-type $\mathrm{SiGe/GaP}$ can now be fabricated with $Z=0.8$ to $0.9 \times 10^{-3} \mathrm{~K}^{-1}$ in an overdoped condition. Heat treatments are being developed to achieve $Z=1.0 \times 10^{-3} \mathrm{~K}^{-1}$ for these samples. Figure 7 gives the results showing nine samples with $Z$ between 0.85 and $1.0 \times 10^{-3} \mathrm{~K}^{-1}$. The $p$-leg $Z$ will be increased to 0.70 to $0.75 \times 10^{-3} \mathrm{~K}^{-1}$ by adding inert scattering centers (50 to $100 \mathrm{~A}$ in size) to reduce the thermal conductivity. The status of this work is given on Fig. 8. Once the inert scattering centers are proven for the p-leg , the method will be applied to the n-leg and the resulting increase should result in a combined $Z=1.0 \times 10^{-3} \mathrm{~K}^{-1}$ over the temperature range of interest. In the meantime, modules and multicouples will be on test to demonstrate the $Z=0.85 \times 10^{-3} \mathrm{~K}^{-1} \mathrm{SiGe} / \mathrm{GaP}$ as required to meet the SP-100 performance specification. The thermoelectric development project plan is depicted in Fig. 9.

\section{Advanced Materials}

Materials development is necessary to assure the success of all advanced power systems. A comprehensive program is underway at NASA Lewis to develop composite radiator fin materials (covered under Thermal Management), advanced refractory materials, and advanced refractory composites. In addition, a data base must be developed to qualify all critical materials of construction at their design operating conditions. Materials include PWC-11, IN-718, U-720, $\mathrm{Gr} / \mathrm{Cu}, \mathrm{W} / \mathrm{Nb}$, and $\mathrm{MoHfC} / \mathrm{Nb}$. Long term stability of PWC-11 has been proven (Fig. 10) as has the strength advantage of properly produced alloy compared to both $\mathrm{Nb}-1 \mathrm{Zr}$ and out-of-spec alloy (Fig. 11). A plan for the development of PWC-11 has been proposed by NASA Lewis to the SP-100 Interface Control Board and is shown in Fig. 12.

Refractory wire reinforced composites provide another significant increase in strength over PWC-11, as illustrated in Fig. 13. Tungsten lamp filament wires and $\mathrm{MoHfC}$ wires are under consider- ation as reinforcement for a $\mathrm{Nb}$ matrix. The elements and the plan for refractory composite development are given in Fig. 14.

Materials under consideration for Stirling power converter construction include Inconel-718 and Udimet-720 at $1050 \mathrm{~K}$ and a list of refractory materials for the $1300 \mathrm{~K}$ Stirling (Table 2). While the refractory Stirling will not be completed under the baseline program, the technology groundwork and initial system designs need to be in place to allow timely completion of the program.

\section{Thermal Management}

The goal of the thermal management effort is to develop heat input and heat output concepts optimized for both static and dynamic power conversion systems using nuclear heat sources. Specific goals include no single point failures, and development of low mass high efficiency components such as pumps, heat exchangers and radiators. Specific goals for radiators include $5 \mathrm{~kg} / \mathrm{m}^{2}$ specific mass, survivability up to 10 years in the space environment, at 0.99 probability level.

The thermal management project plan is shown in Fig. 15. The advanced radiator concepts contracts are in Phase IV - developing subsystems for an $875 \mathrm{~K}$ concept for thermoelectric conversion and a $600 \mathrm{~K}$ concept for Stirling conversion. Space Power Incorporated is developing a LiNaK pumped loop system for $600 \mathrm{~K}$ applications. The loop, with cooling fins in place, will be demonstrated in a simulated space environment during Phase IV. Rockwell International is developing a carbon-carbon structure wherein the fin and heat pipe is an integrated structure and a metallic liner is inserted for heat pipe fluid containment. For the thermoelectric conversion rejecting heat at $875 \mathrm{~K}$, the fluid is potassium and the liners are titanium or niobium. The fin structure methods are developed (Fig. 16) and liner structures with braze materials have been identified

The high conductivity composite fin development at NASA Lewis is outlined on Fig. 17. The objective is to produce a composite $\mathrm{Gr} / \mathrm{Cu}$ fin attached to a titanium heat pipe to operate in the 475 to $500 \mathrm{~K}$ temperature regime. Composite fins have been produced, tailoring of the coefficient of thermal expansion is underway, and braze materials and techniques have been selected for attachment of the two. 
Another development for water heat pipes is the fiber-fabric concept at DOE/PNL. The fabric is used to contain the high working fluid $\left(\mathrm{H}_{2} \mathrm{O}\right)$ pressure at 475 to $500 \mathrm{~K}$, and also to provide protection against meteoroid and debris penetration. An 0.025 titanium liner/Nextel fabric heat pipe is under test at NASA Lewis. The next generation 0.0025 in. thick titanium liner with carbon fabric is in production at PNL.

A significant effort at NASA Lewis is the enhancement of radiator surface emissivity through surface morphology changes. Some results of atomic oxygen texturing on carbon-carbon composites are presented in Fig. 18. Arc texturing of copper at 12 to $15 \mathrm{~A}$ and 20 to $100 \mathrm{~Hz}$ produced an emittance of 0.83 at $550 \mathrm{~K}$. Tests presently underway will determine the durability of the texturing and the stability of any surfaces particles in residence after texturing.

\section{Power Management}

Power Management is the link between the electrical power source and the user. The work under CSTI High Capacity Power in FY91 has concentrated on three tasks: (1) power conditioning for a free piston Stirling power converter, (2) radiation effects on semiconductor power switches, and (3) temperature and frequency effects on soft magnetic materials.

Reference 5 presents recent results on the dynamic analyses of free-piston Stirling Engines. A test laboratory at NASA Lewis is currently operating a SPIKE engine (1 kWe free-piston) to determine the influence of ac and dc loads on engine/alternator dynamic behavior and controllability. The first system test was recently completed and control system characterization is proceeding. Four SPIKE engines are available to include multiple engine synchronization and control in the test series.

Commercial semiconductor power switches have been evaluated for radiation effects at the SP-100 user-interface specified values of $0.5 \mathrm{Mrad}$ gamma and $10^{13} \mathrm{n} / \mathrm{cm}^{2}$ fluence. Of the power devices tested to date, phase-controlled and invertor-type thyristors seem best suited for the SP-100 application. At $2 \times 10^{13} \mathrm{n} / \mathrm{cm}^{2}$ fluence, however, the thyristors deteriorate and temperatures to $360 \mathrm{~K}$ do not anneal the damage. SiC devices are under development at NASA Lewis with the goal of
$500 \mathrm{~K}$ temperature capability as well as resistance to radiation effects.

Reference 6 gives temperature and frequency effects on soft magnetic materials. Both crystalline and amorphous materials have been investigated at frequencies to $50 \mathrm{kHz}$ and temperatures to $575 \mathrm{~K}$. References 7 and 8 give results to date.

\section{System Diagnostics}

Space power systems require electrical current sensors which are immune to electromagnetic interference and static discharge effects. Fiber-optic sensors can meet both requirements and are also lightweight and can be placed at reasonable distances from central electronics.

A fiber-optic current sensor, initially developed in 1990, needed improved vibration tolerance and better accuracy over a wider temperature range. The improved sensor, developed at NIST, is ready for testing at NASA Lewis to verify the accuracy of \pm 1 percent full scale over a -65 to $125^{\circ} \mathrm{C}$ temperature range with vibration tolerance of $18 \mathrm{~g}$ random and $20 \mathrm{~g}$ sinusoidal from 5 to $2000 \mathrm{~Hz}$.

The fiber-optic voltage sensor, also under development at NIST, is still sensitive to vibration. Single mode fibers are being applied to both input to the sensor head and output to solve the vibration problem.

Reference 9 gives an update on both current and voltage sensor development.

\section{Environmental Interactions}

Space systems of the future will be larger, longer-lived, and higher powered. They must operate predictably and reliably in their total environment and be compatible with user requirements. Systems involving nuclear power generation in the range of 10 to $1000 \mathrm{kWe}$ are under consideration for lunar and planetary power supplies. Interactions with lunar and Martian dust as well as the Martian atmosphere need to be understood. Large power systems above $1 \mathrm{MWe}$ for nuclear electric propulsion, will interact strongly with the plasma and field environments, both natural and system generated. The high voltages anticipated for high power systems may also induce electrical breakdown of neutral gases. Electric thrusters will generate neutral and 
low energy plasmas as well as the primary beam, which will contribute significantly to the local environment.

$S^{3}$ corporation performed the first computer simulation of the SP-100 configuration with NASCAP/LEO and NASCAP/POLAR to determine interactions with the space plasma. Mitigation strategies were developed in conjunction with GE (SP-100 Contractor) to alleviate possible problems at the joint between the user and the spacecraft. The computer code is being extended to cover interplanetary space. As time and funding allow, simulations of nuclear electric propulsion systems will be done, as well as simulation of lunar and Martian dust and the Martian atmosphere.

Samples of interest to SP-100 and the CSTI High Capacity Power Program will be flown on the Effects of Oxygen Interactions on Materials (EOIM-3) experiments scheduled for STS-46 in June 1992. The space flight results will be correlated with theory and with ground experiments based upon previous results and a Kapton "standard sample" flown on all experiments. Samples selected for flight test include refractory metals $\mathrm{Nb}-1 \mathrm{Zr}$, Mo-13Re, PWC-11, radiator coating, superalloys for Stirling, spacecraft structural materials 6061-T6A, 304SS, and SP-100 multilayer insulator materials $W$ thin film/A1, Mo thin film/A1.

\section{Summary}

The NASA CSTI High Capacity Power Program is a broad-based effort to provide significant improvements in the technology associated with space nuclear power and its relationship with the mission environment. The inherent advantages of nuclear reactor power-compactness, high power at low mass, long life and reliability - must be coupled with aerospace technology which can capitalize on these advantages. The CSTI High Capacity Power Program supports and advances all the nonnuclear aspects of the national SP-100 Space Nuclear Reactor Program. The project described herein will provide a technology demonstration of a $1050 \mathrm{~K}$ Stirling space power system, and lay the groundwork for a $1300 \mathrm{~K}$ Stirling space power system to utilize the full capability of the SP-100 reactor. In addition, the thermoelectric technology to demonstrate the $Z=0.85 \times 10^{-3} \mathrm{~K}^{-1}$ design goal will be established and the capability to reach $Z=1.0 \times 10^{-3} \mathrm{~K}^{-1}$ with
SiGe/GaP will be demonstrated. The focused nature of the project will ensure that the technology advances are in place by the late 1990's so that NASA's long-term goals in civil space exploration and exploitation may be achieved.

\section{References}

1. Mason, L., Bloomfield, H., and Hainley, D., "SP-100 Power System Conceptual Design for Lunar Base Applications," NASA TM-102090, 1989.

2. "NASA's Need for Advanced Nuclear Power Sources," Report for the Subcommittee on Commerce, Science, and Transportation, U.S. Senate, Jan. 1989.

3. Winter, J., "CSTI High Capacity Power," NASA TM-102059, 1989.

4. Cairelli, J., Swec, D., Wong, W., and Doeberling, T., "Update on Results of SPRE Testing at NASA Lewis," Energy and the Environment: A Continuing Partnership (26th IECEC), Vol. 5, American Nuclear Society, LaGrange Park, IL, 1991, pp. 217-222. (Also, NASA TM-104425.)

5. Kankam, M., and Rauch, J., "Comparative Study of Dynamic Analyses of Free-Piston Stirling Engines," Energy and the Enviornment: A Continuing Partnership (26th IECEC), Vol. 5, American Nuclear Society, LaGrange Park, IL, 1991, pp. 314-319. (Also, NASA TM-104491.)

6. Schwarze, G., Niedra, J., and Wieserman, W. "High Temperature, High Frequency Experimental Investigation of Soft Magnetic Materials," First International High Temperature Electronics Conference, Albuquerque, NM, June 1991.

7. Wieserman, W.R., Schwarze, G.E., and Niedra, J.M., "Comparison of High Frequency, High Temperature Core Loss and B-H Loop Characteristics of an $80 \mathrm{Ni}$-Fe Crystalline Alloy and Two Iron-Based Amorphous Alloys," Proc. Eighth Symposium on Space Nuclear Power Systems, M.S. El-Greuk and M.D. Hoover, eds., Conf-910116, Part 3, DOE, 1991, pp. 974-981. 
8. Wieserman, W.R., Schwarze, G.E., and

Niedra, J.M., "Comparison of High Temperature, High Frequency Core Loss and Dynamic B-H Loops of Two $50 \mathrm{Ni}$-Fe Crystalline Alloys and an Iron-Based Amorphous Alloys," Energy and the Environment: A Continuing Partnership (26th IECEC), Vol. 1, American Nuclear Society, LaGrange Park, IL, 1991, pp. 165-170.
9. Patterson, R., Rose, A., Tang, D., and Day, G. "Fiber-Optic Sensors for Aerospace Electrical Measurements: An Update," Energy and the Environment: A Continuing Partnership (26th IECEC), Vol. 2, American Nuclear Society, LaGrange Park, IL, 1991, pp. 180-183. (Also, NASA TM-104454.)

TABLE 1. - CSTI HIGH CAPACITY POWER

[Baseline funding estimate- $\$ \mathrm{k}$.]

\begin{tabular}{|c|c|c|c|c|c|c|c|c|c|}
\hline $\begin{array}{c}\text { Ele- } \\
\text { ment } \\
\text { number }\end{array}$ & $\begin{array}{l}\text { Program } \\
\text { element }\end{array}$ & FY90 & FY91 & FY92 & FY93 & FY94 & FY95 & FY96 & \\
\hline \multirow[t]{3}{*}{11} & $\begin{array}{l}\text { Conv. system for } \\
\text { nuclear application }\end{array}$ & & & & & & & & \\
\hline & 11-1 Stirling & 5825 & 5726 & 5522 & 2257 & 2310 & 2494 & 2511 & (a) \\
\hline & 11-2 Thermoelectrics & 800 & 400 & 600 & 300 & 300 & ---- & --- & \\
\hline 21 & Thermal management & 1800 & 1391 & 1265 & 600 & 600 & 700 & 800 & (a) \\
\hline 31 & Power management & 250 & 100 & 200 & 100 & 100 & 100 & 100 & (a) \\
\hline 41 & Systems diagnostics & 100 & 100 & 100 & 50 & 50 & 50 & 50 & (a) \\
\hline \multirow[t]{4}{*}{51} & $\begin{array}{l}\text { Environmental inter- } \\
\text { actions }\end{array}$ & 175 & 54 & 100 & 50 & 50 & 50 & 50 & (a) \\
\hline & Total net R\&D & 8950 & 7771 & 7787 & 3357 & 3410 & 3394 & 3511 & \\
\hline & Program support & 1457 & 2280 & 2100 & 892 & 933 & 1042 & 1109 & \\
\hline & Total & 10407 & 10051 & 9887 & 4249 & 4343 & 4436 & 4620 & \\
\hline
\end{tabular}

${ }^{\mathrm{a}}$ Continuing. 
TABLE 2. - HIGH CAPACITY POWER REFRACTORY MATERIAL CANDIDATES FOR $1300 \mathrm{~K}$ STIRLING

\begin{tabular}{|c|c|c|c|c|c|c|c|c|c|}
\hline $\begin{array}{c}\text { Base } \\
\text { material }\end{array}$ & $\begin{array}{c}\mathrm{MP} \\
\mathrm{K}\end{array}$ & $\begin{array}{c}\rho, \\
g / c c\end{array}$ & $\begin{array}{l}\text { Alloy } \\
\text { name } \\
\end{array}$ & $\begin{array}{c}\text { Composition, } \\
\text { wt \% }\end{array}$ & Joinability & Fabricability & $\begin{array}{c}\text { Alloy } \\
\text { availability }\end{array}$ & $\begin{array}{c}\text { Data } \\
\text { availability }\end{array}$ & $\begin{array}{c}\begin{array}{c}\text { Vacuum, } \\
\text { torr }\end{array} \\
\end{array}$ \\
\hline W & 3680 & 19.3 & W-25Re-HfC & $\begin{array}{l}24 \text { to } 26 \% \mathrm{Re} \\
1 \% \mathrm{HfC}\end{array}$ & 5 & 4 & 4 & 3 & $10^{-6}$ \\
\hline $\mathrm{Ta}$ & 3270 & 16.6 & ASTAR-811C & $\begin{array}{l}8 \% \mathrm{~W} \\
1 \% \mathrm{Re} \\
1 \% \mathrm{HfC}\end{array}$ & 8 & 8 & 10 & 5 & $10^{-8}$ \\
\hline Mo & 2880 & 10.2 & $\begin{array}{l}\text { TZM } \\
\text { TZC }\end{array}$ & $\begin{array}{l}0.08 \% \mathrm{Zr} \\
0.5 \% \mathrm{Ti} \\
1.25 \% \mathrm{Ti} \\
0.1 \% \mathrm{Zr} \\
0.15 \% \mathrm{C} \\
\end{array}$ & $\begin{array}{l}2 \\
2\end{array}$ & $\begin{array}{l}8 \\
6\end{array}$ & $\begin{array}{l}10 \\
10\end{array}$ & $\begin{array}{l}4 \\
4\end{array}$ & $\begin{array}{l}10^{-6} \\
10^{-6}\end{array}$ \\
\hline $\mathrm{Mo} / \mathrm{Re}$ & 2780 & 15.5 & Mo-47.5 Re & $\begin{array}{l}47.5 \% \mathrm{Re} \\
\mathrm{bal} \mathrm{Mo}\end{array}$ & 8 & 6 & 8 & 3 & $10^{-6}$ \\
\hline $\mathrm{Nb}$ & 2740 & 8.6 & $\begin{array}{l}\text { FS-85 } \\
\text { B-88 }\end{array}$ & $\begin{array}{l}11 \% \mathrm{~W} \\
28 \% \mathrm{Ta} \\
1 \% \mathrm{Zr} \\
27 \% \mathrm{~W} \\
2 \% \mathrm{HfC}\end{array}$ & 7 & 7 & 4 & 2 & $10^{-8}$ \\
\hline & & & $C-103$ & $\begin{array}{l}10 \% \mathrm{Hf} \\
1 \% \mathrm{Ti} \\
0.7 \% \mathrm{Zr}\end{array}$ & 10 & 10 & 10 & 7 & $10^{-8}$ \\
\hline & & & PWC-11 & $\begin{array}{l}1 \% \mathrm{Zr} \\
0.1 \% \mathrm{C}\end{array}$ & 10 & 10 & 10 & 7 & $10^{-8}$ \\
\hline & & & $\mathrm{Nb}-1 \mathrm{Zr}$ & & 10 & 10 & 10 & 8 & $10^{-8}$ \\
\hline
\end{tabular}




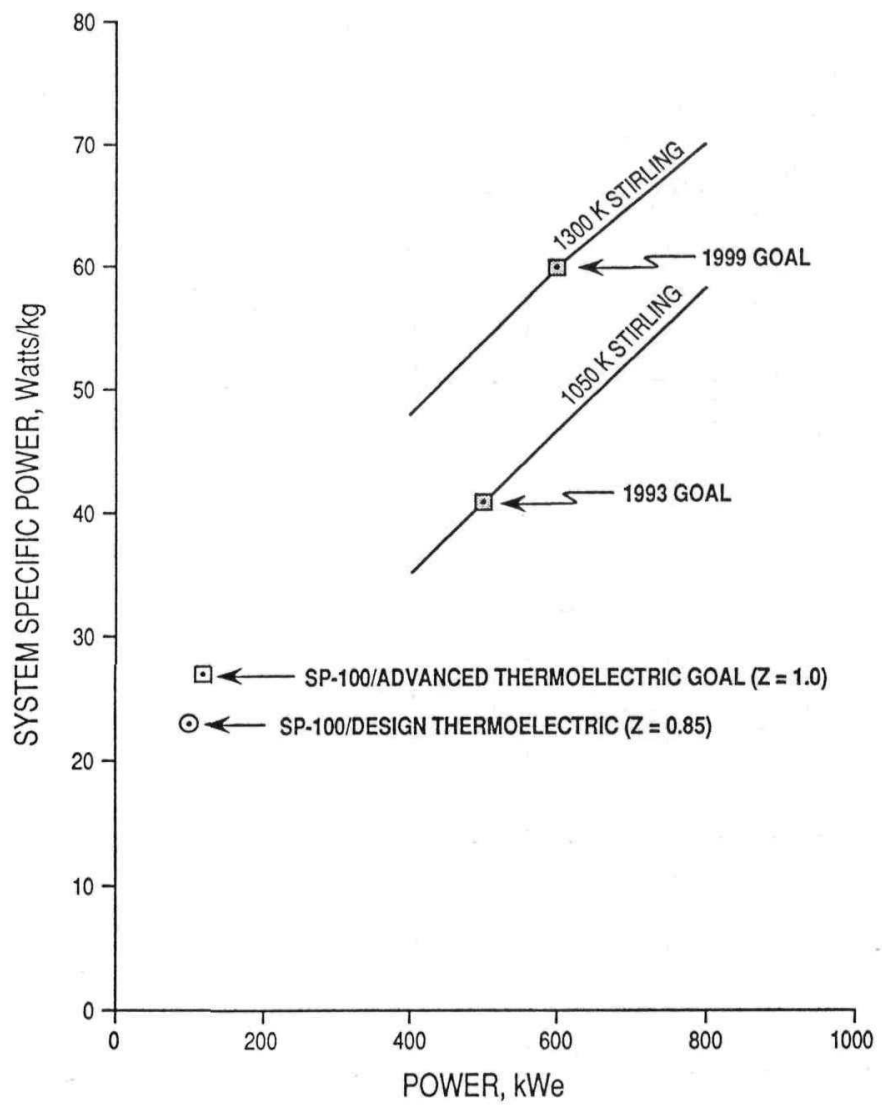

Figure 1.-Extended SP-100 reactor power system capability.

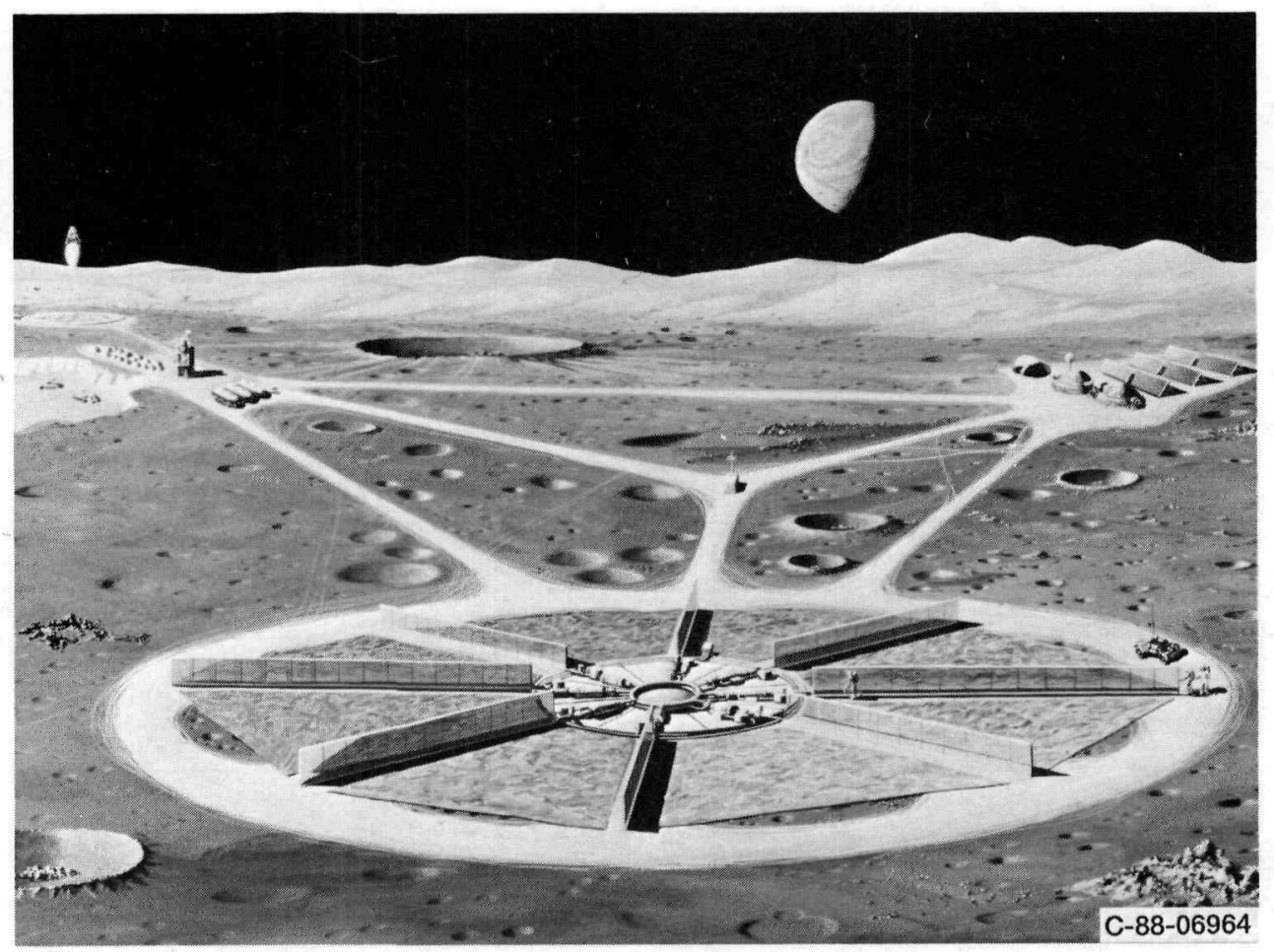

Figure 2.-Conceptual lunar base. 


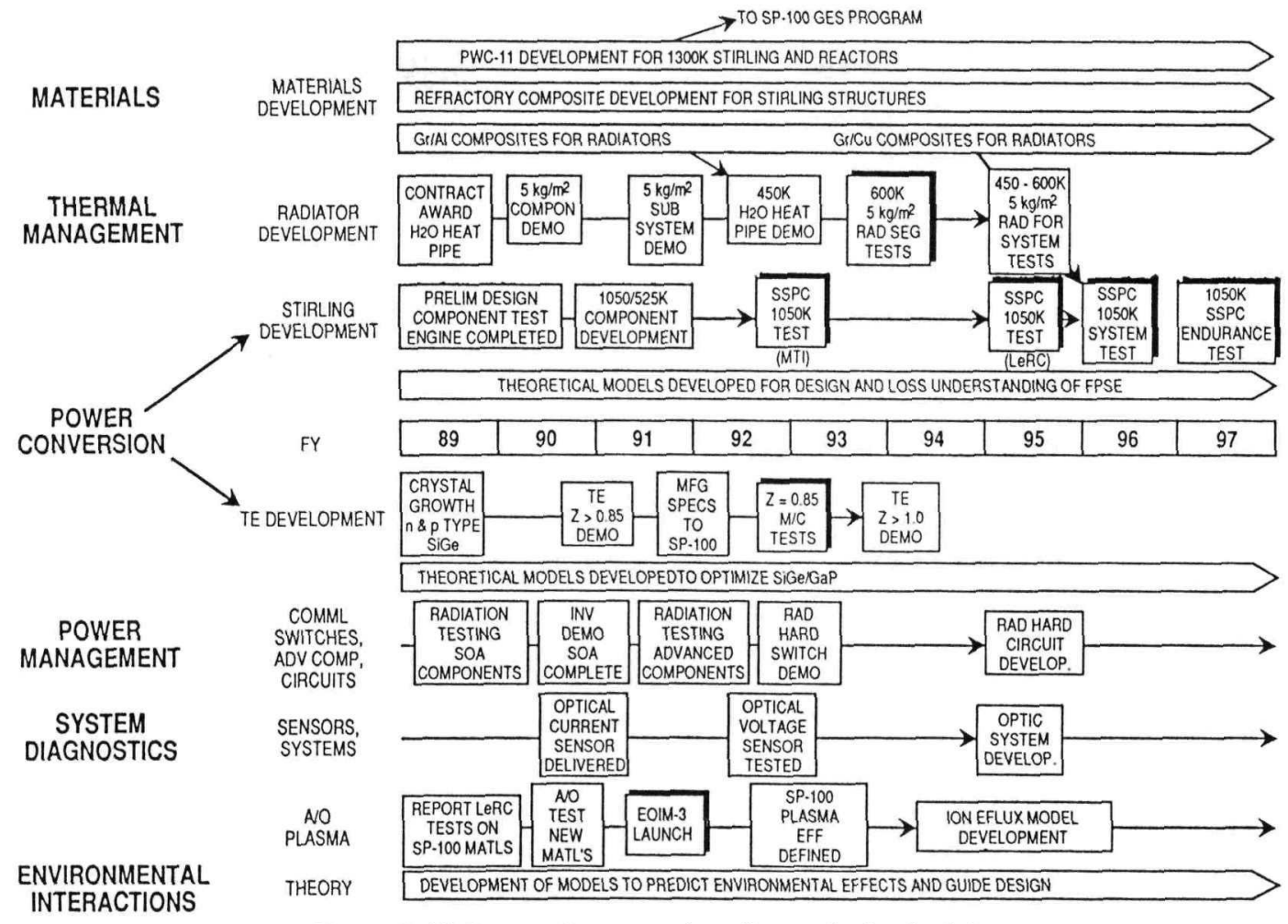

Figure 3.-High capacity power, baseline project schedule.

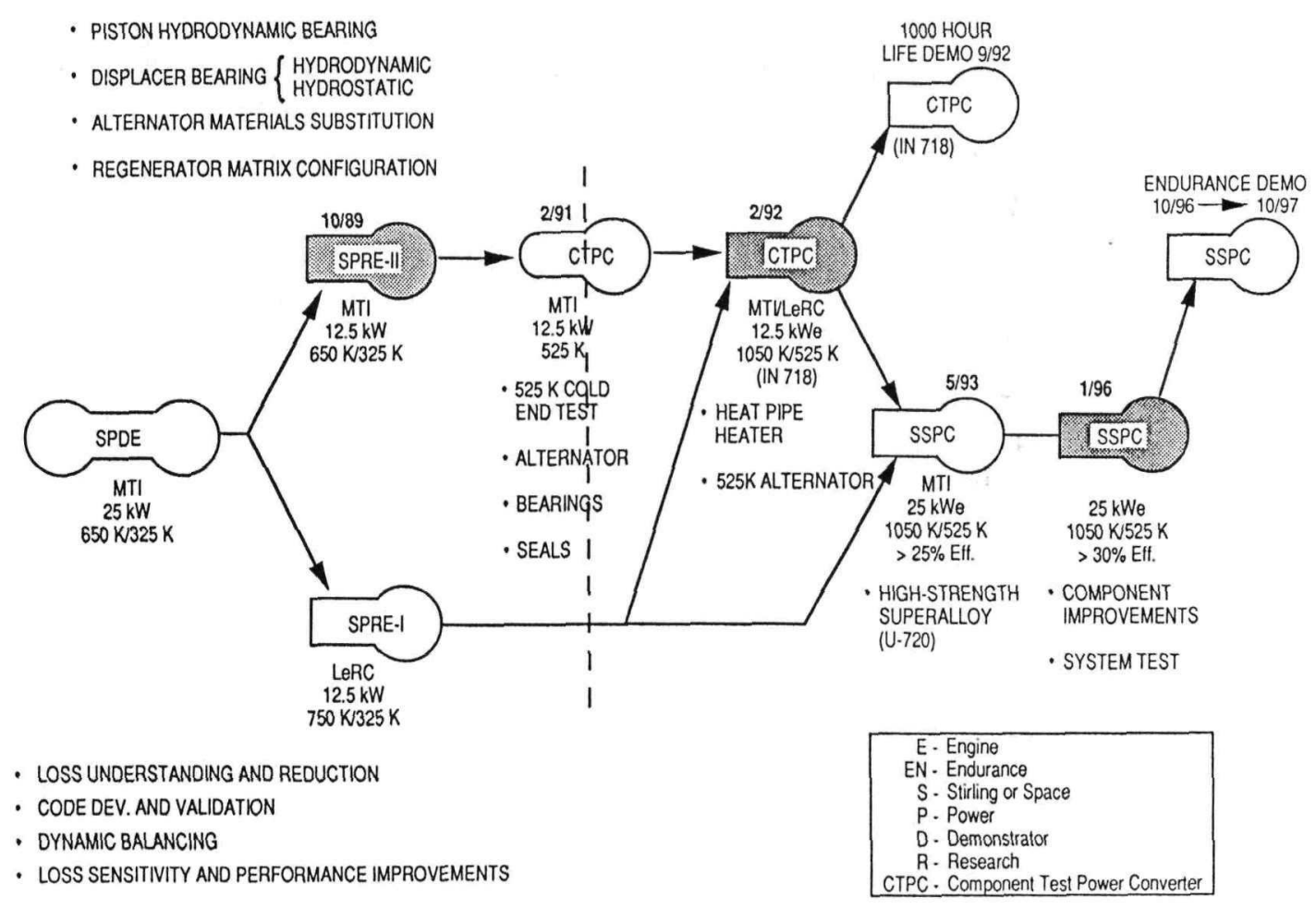

Figure 4.-Stirling development baseline project. 


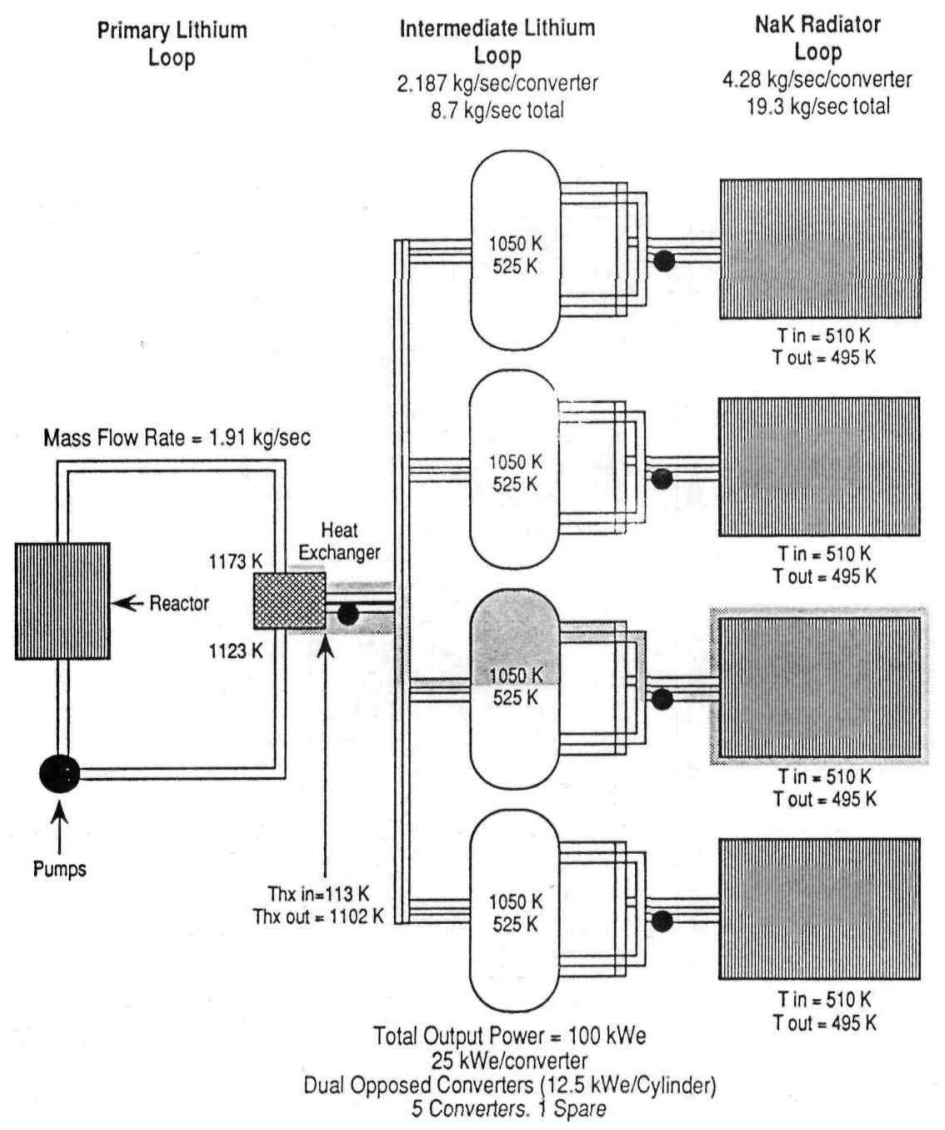

Figure 5.-SP-100/Stirling lunar base.
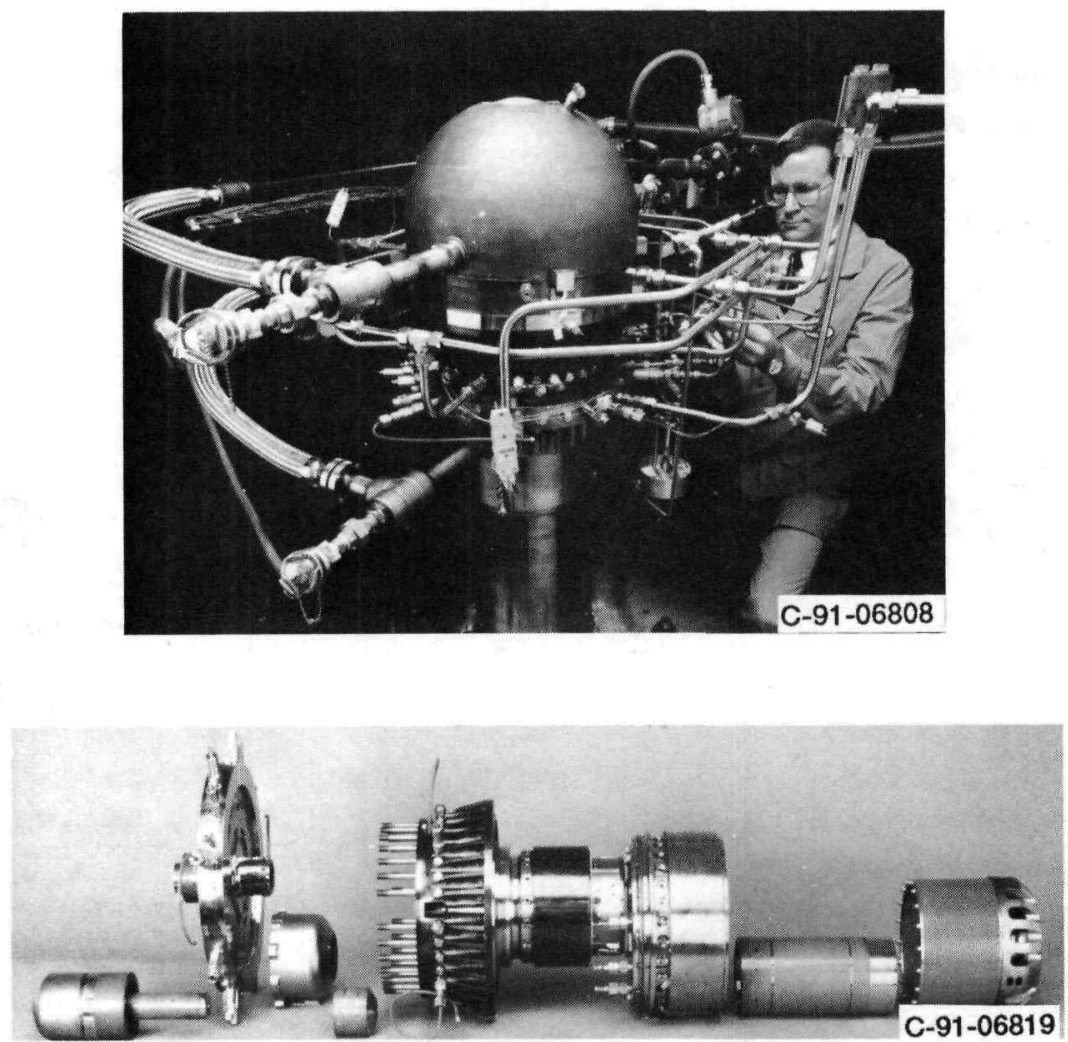

Figure 6.-Component test power converter (CTPC) cold end motoring test. 


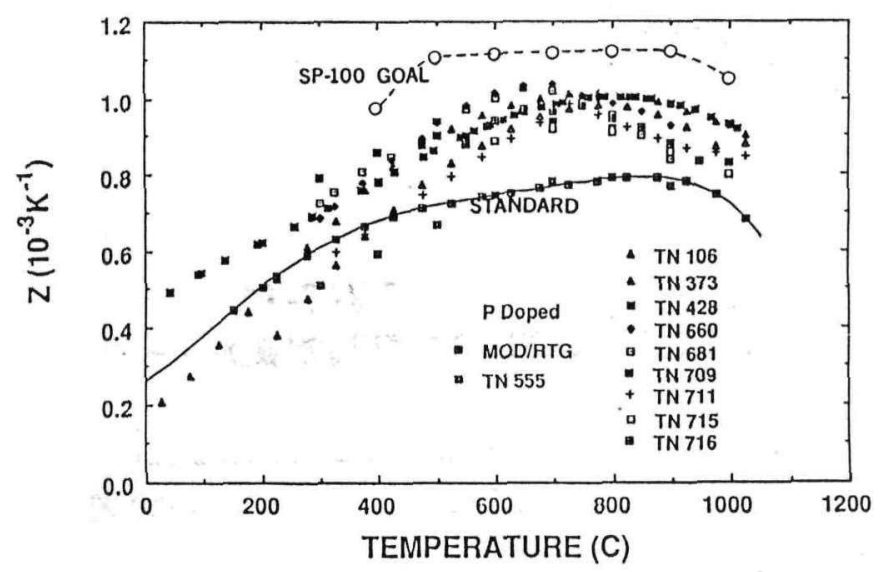

Figure 7.-Improved n-type SiGe/GaP.

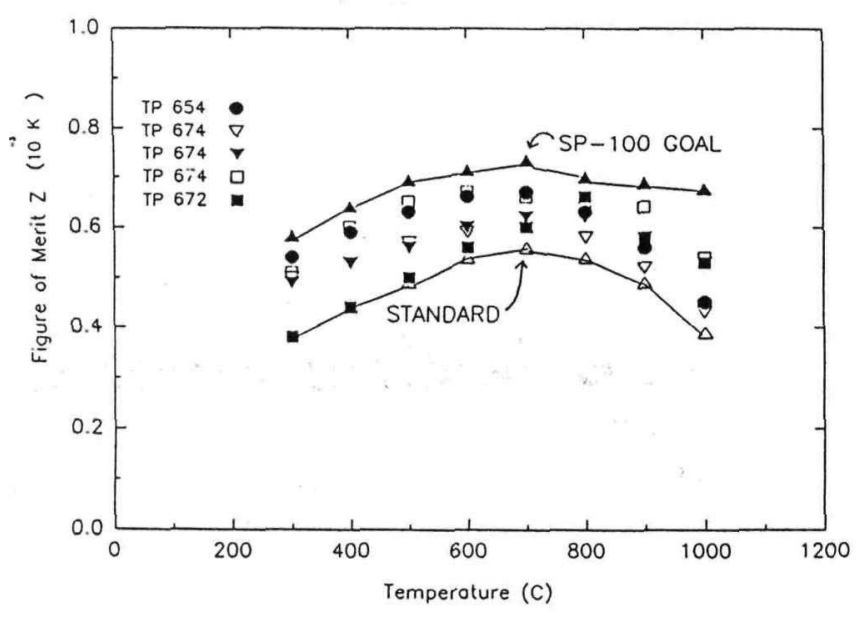

Figure 8.-Z for p-type SiGe.

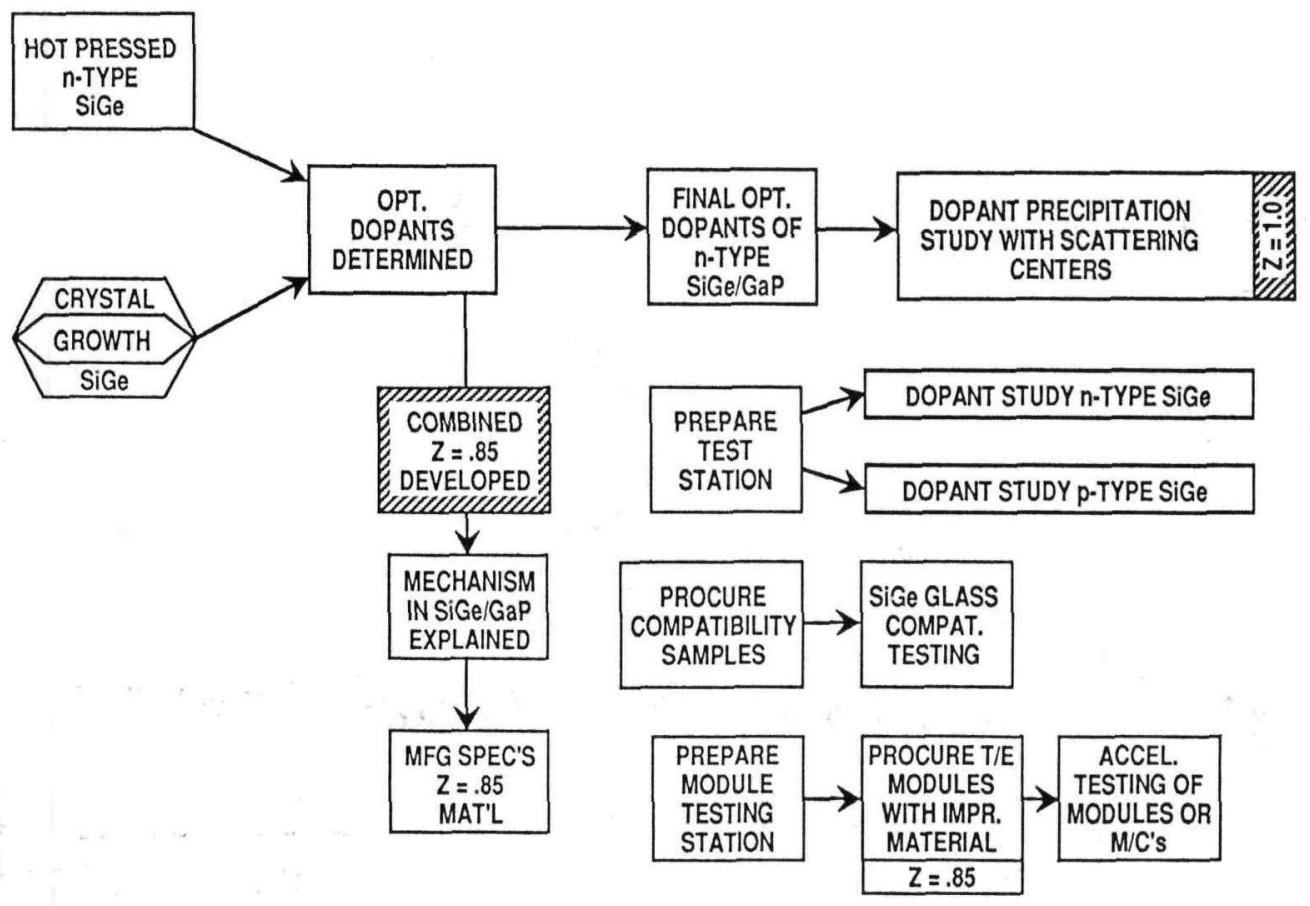

\begin{tabular}{|l|l|l|l|l|l|l|l|}
\hline 89 & 90 & 91 & 92 & 93 & 94 & 95 & 96 \\
\hline
\end{tabular}

Figure 9.-Thermoelectric development . 


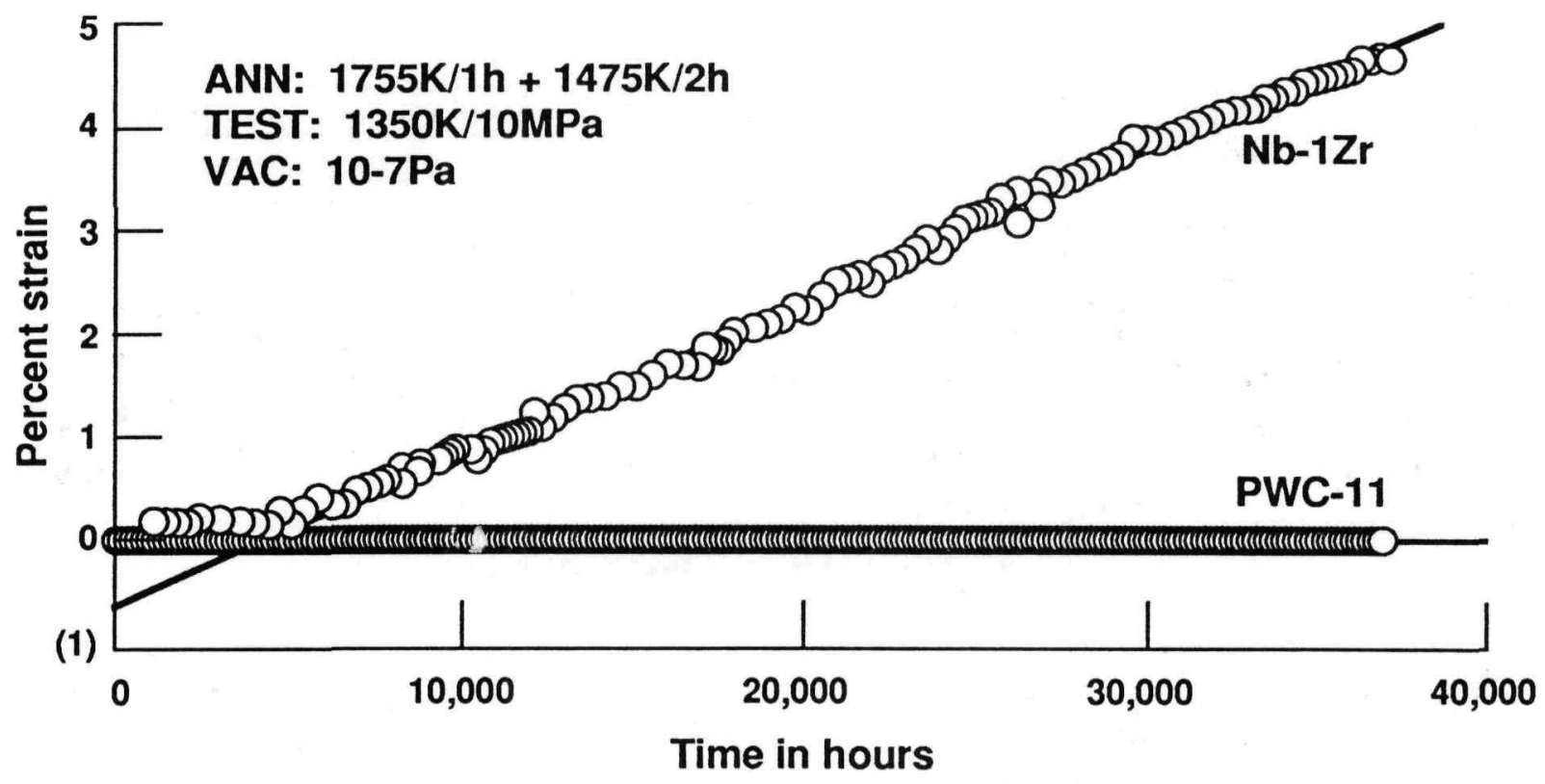

Figure 10.-Creep curves for Nb-1Zr \& PWC-11 (0.06C).

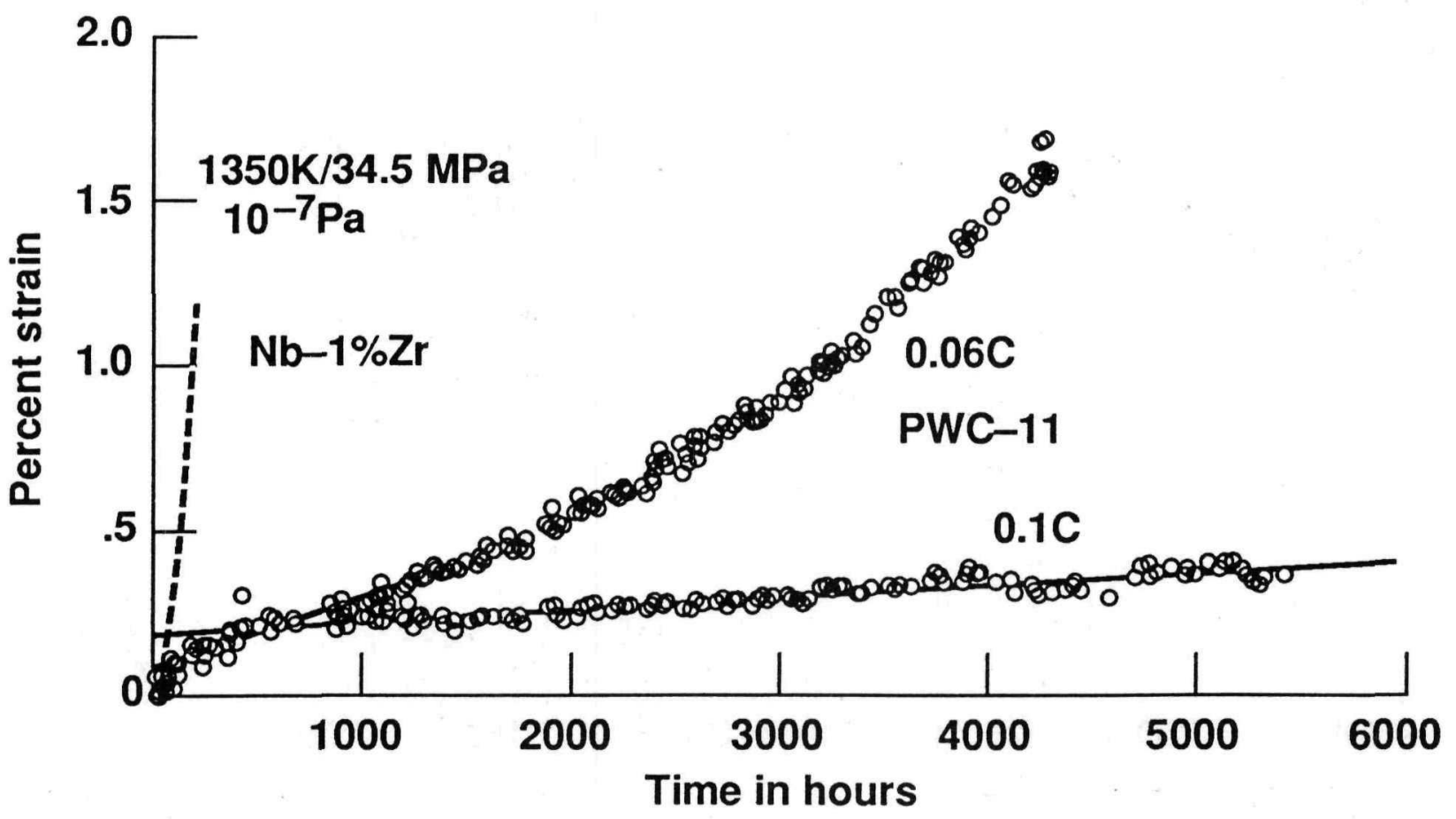

Figure 11.-Creep curves for $\mathrm{Nb}-1 \% \mathrm{Zr}$ and PWC-11. 


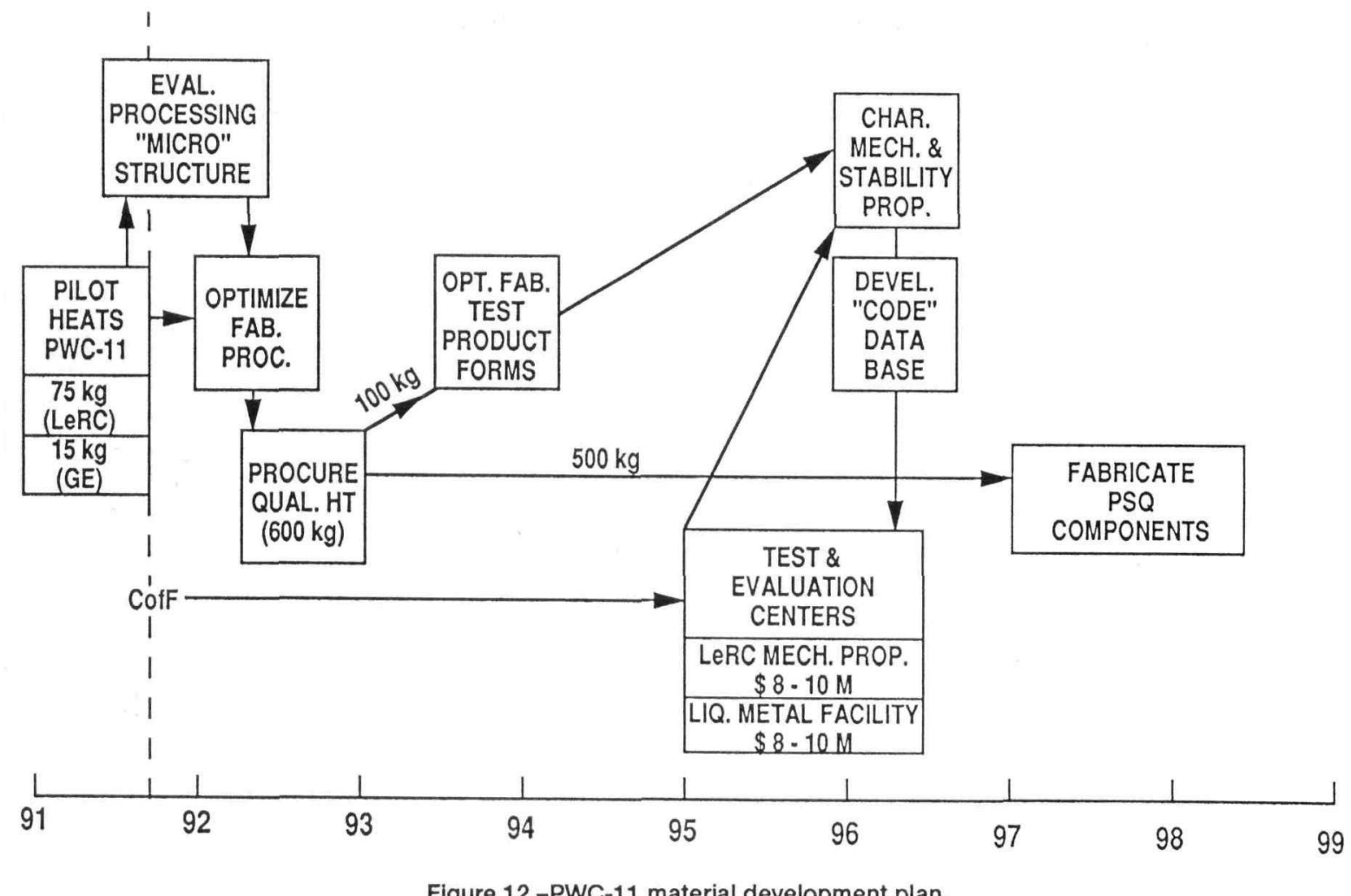

Figure 12.-PWC-11 material development plan.

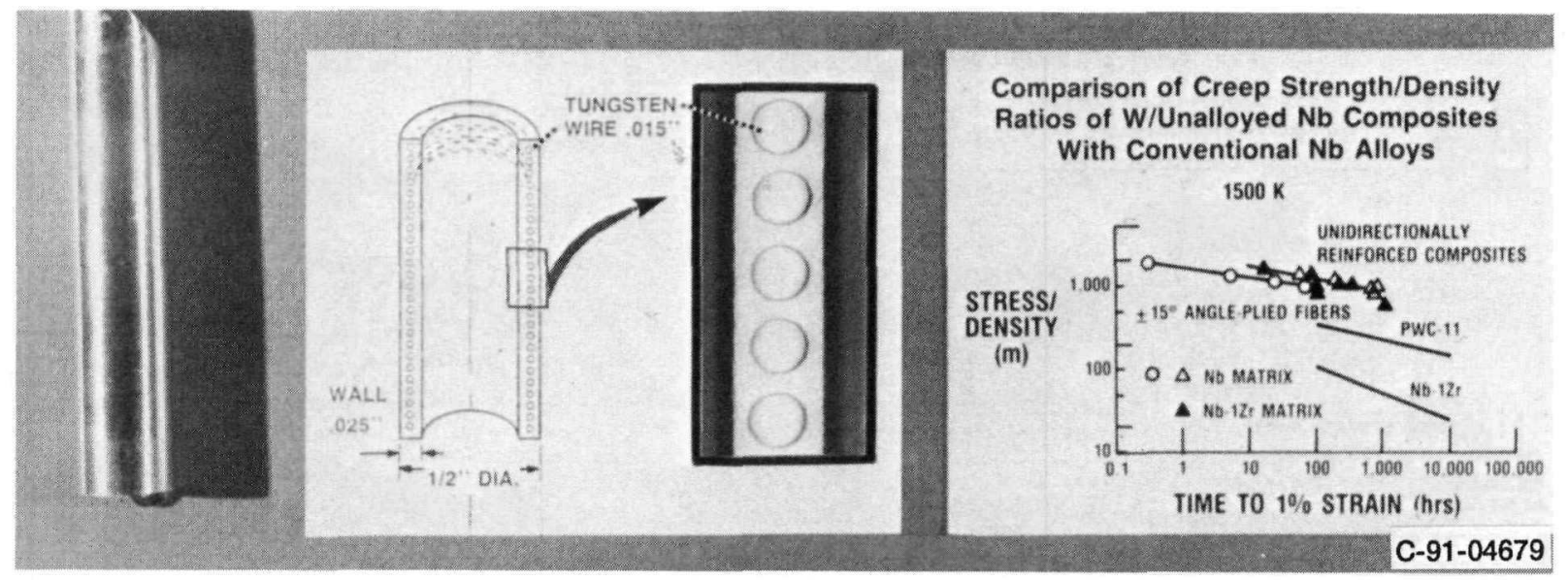

Figure 13.-Tungsten fiber reinforced $\mathrm{Nb}-1 \mathrm{Zr}$ matrix composites for space power applications. Fabricated using arc-spray process invented at NASA-Lewis Research Center. 


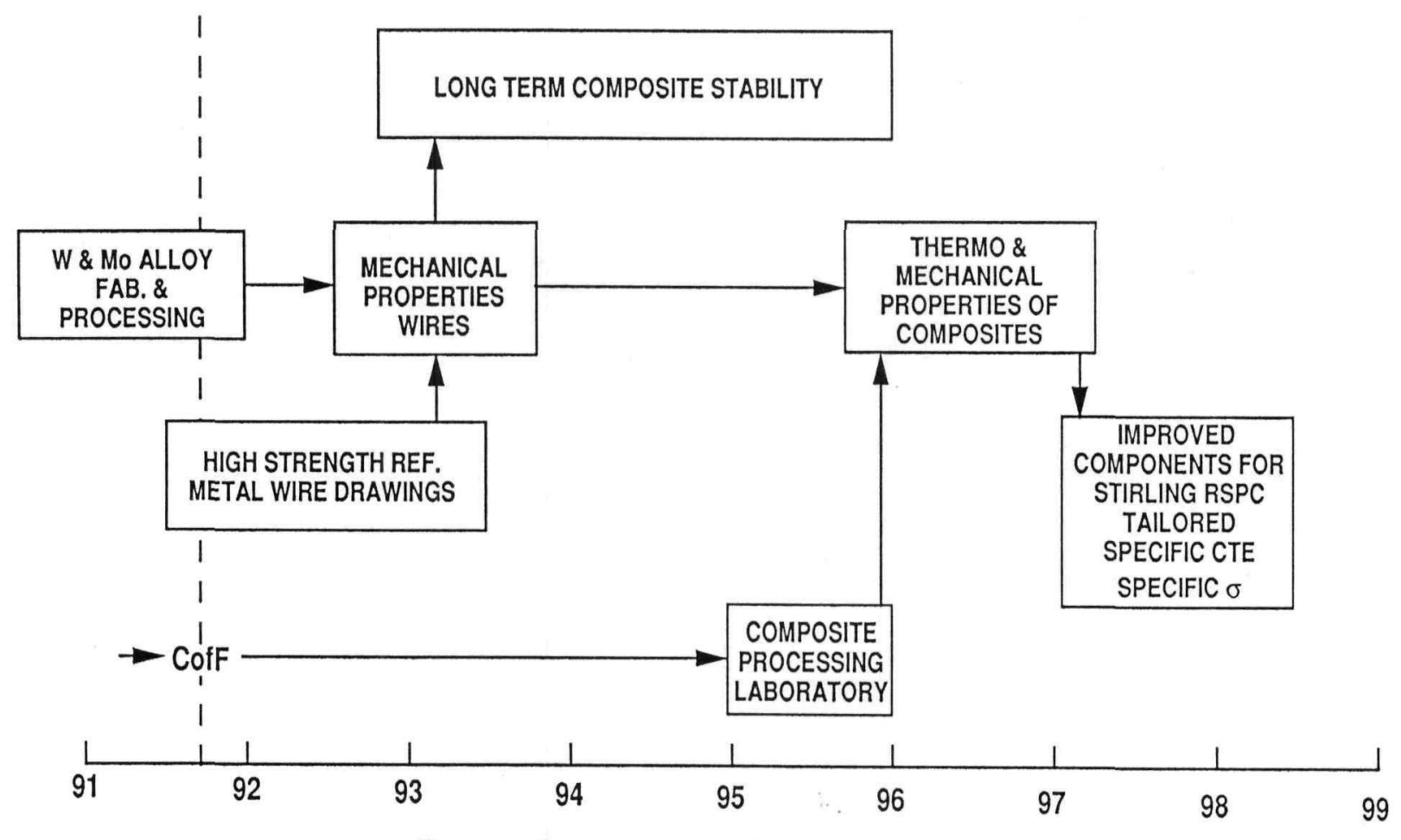

Figure 14.-Refractory composite development plan.

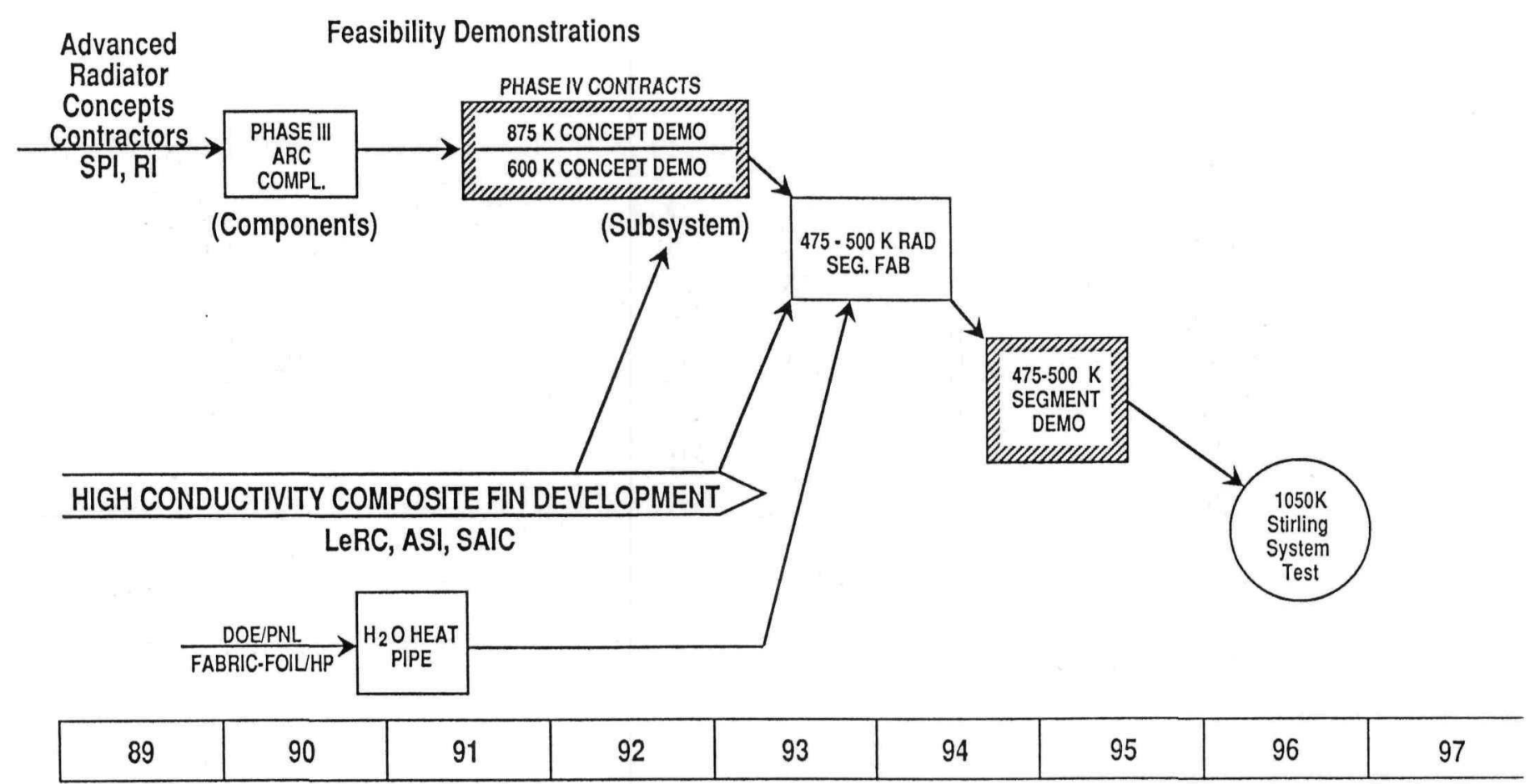

Figure 15.-Thermal management baseline budget plan. 


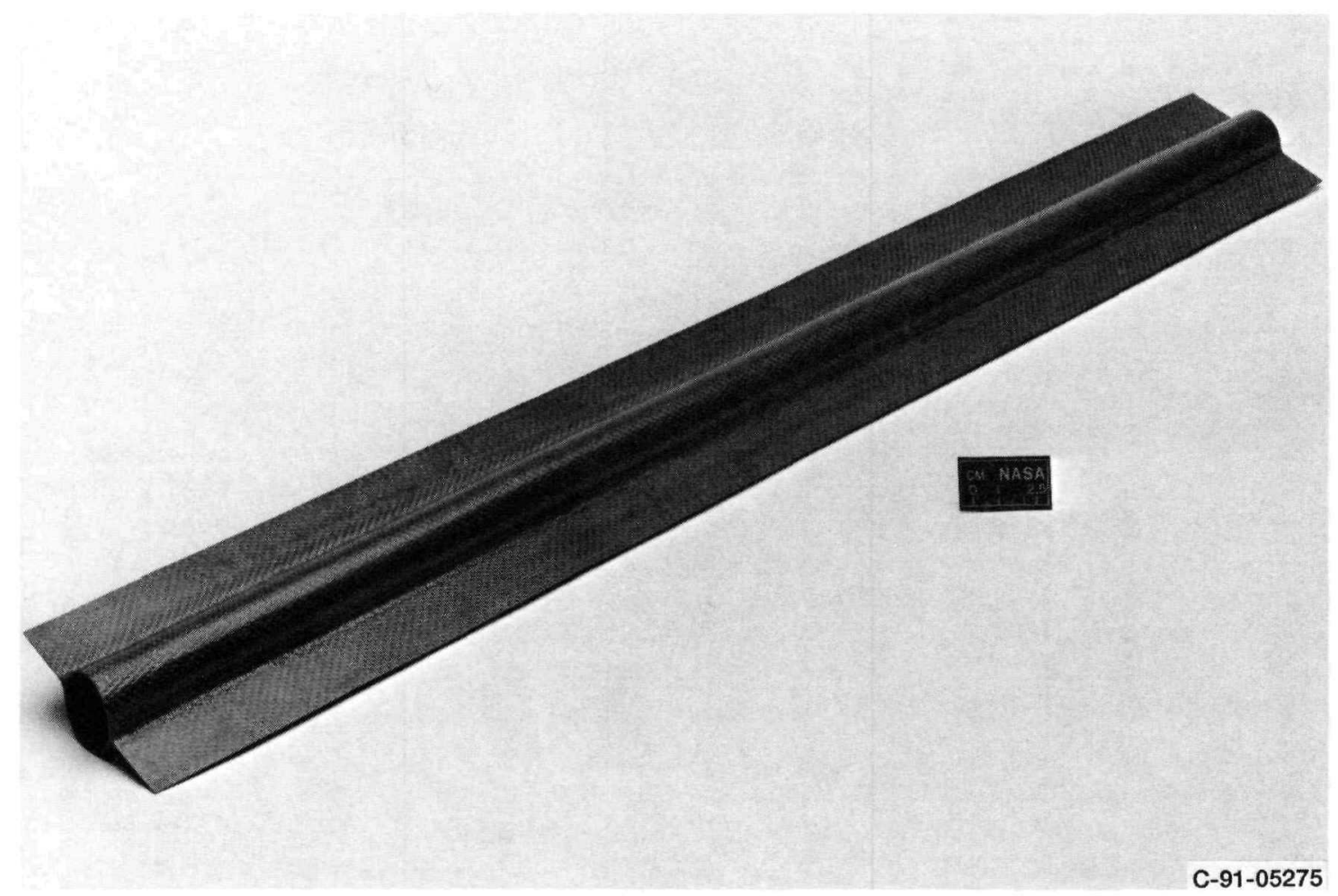

Figure 16.-Carbon-carbon fin heat pipe structure.

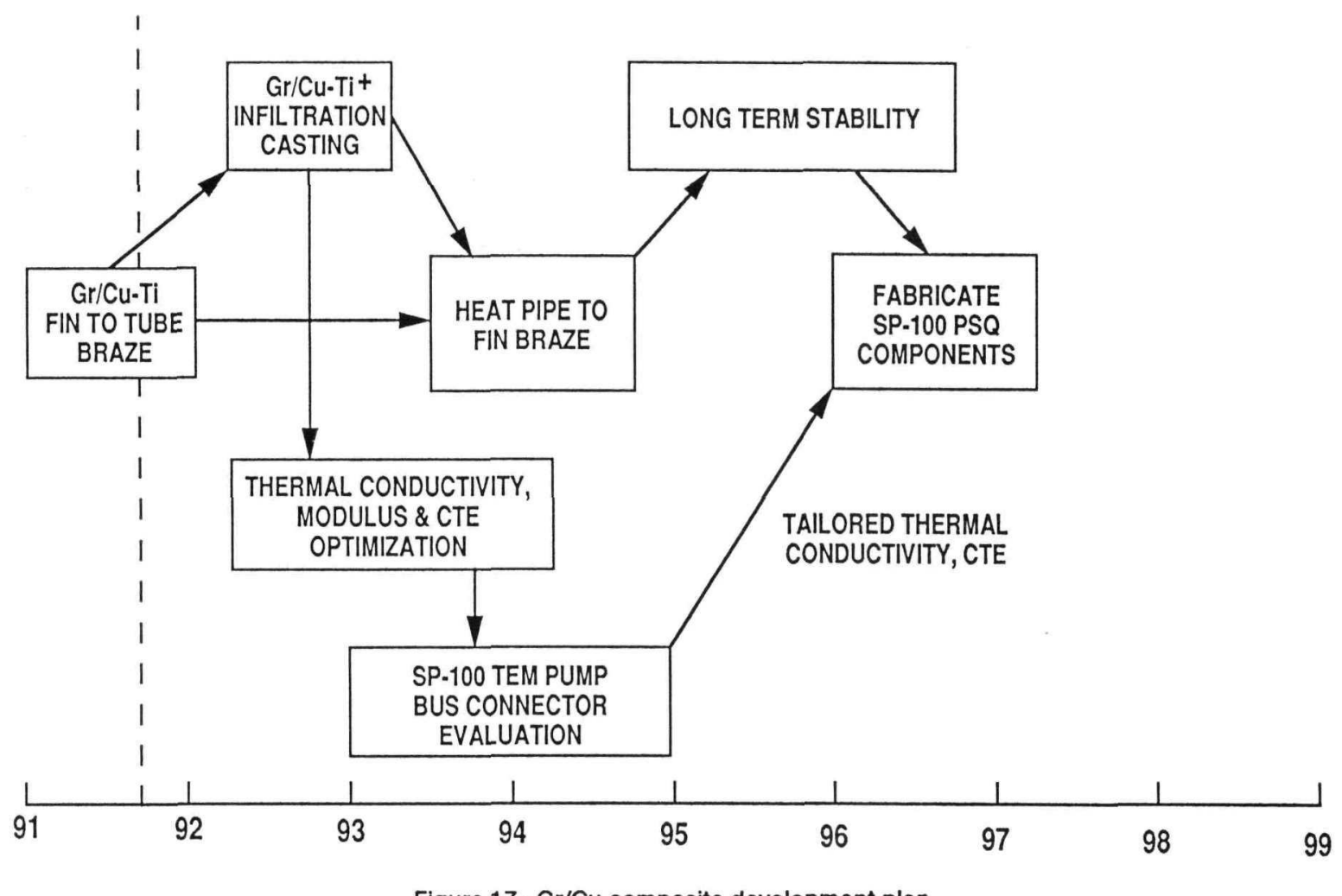

Figure 17.-Gr/Cu composite development plan. 

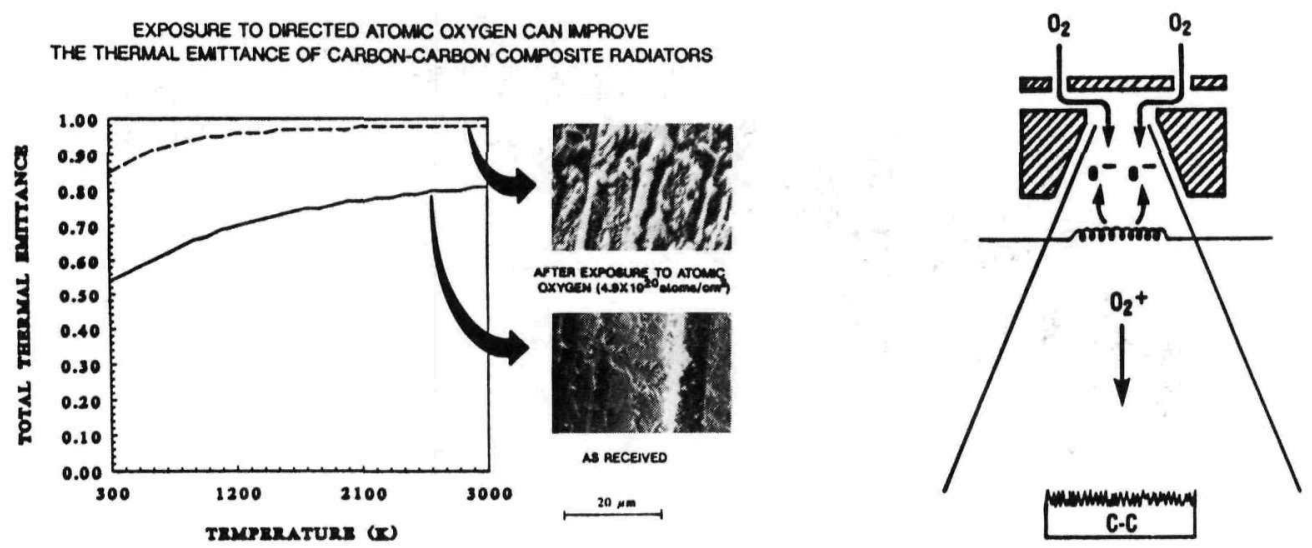

- SIX DIFFERENT TYPES OF C-C COMPOSITES EVALUATED - UNTREATED THERMAL EMITTANCE .45-.82 AT $800 \mathrm{~K}$

- AFTER ANO BEAM TEXTURING THERMAL EMITTANCE .85-.9 AT $800 \mathrm{~K}$

- PEAK EMITTANCE REACHED AT NO EFFECTIVE FLUENCE OF $4 \times 10^{20}$ AT/cm²

- CVD $\mathrm{SIO}_{2}$ COATINGS ON C-C ARE BENEFICIAL

- COATINGS ON UNTEXTURED C-C INCREASE EMITTANCE FROM .67 TO .82 AT $800 \mathrm{~K}$

- COATING PREVENTS MASS LOSS AND PRESERVES EMITTANCE IN AV ENVIRONMENT

- APPLICABLE TO SP-100 AND SOLAR DYNAMIC SYSTEM C-C HEAT PIPE RADIATORS (500-860 K)

Figure 18.-Atomic oxygen beam textured carbon-carbon composites. 
Public reporting burden for this collection of information is estimated to average 1 hour per response, including the time for reviewing instructions, searching existing data sources, gathering and maintaining the data needed, and completing and reviewing the collection of information. Send comments regarding this burden estimate or any other aspect of this Davis Highway, Suite 1204, Arlington, VA 22202-4302, and to the Office of Management and Budget, Paperwork Reduction Project (0704-0188), Washington, DC 20503.

\begin{tabular}{|l|l|l|}
\hline 1. AGENCY USE ONLY (Leave blank) & $\begin{array}{r}\text { 2. REPORT DATE } \\
\text { September 1991 }\end{array}$ & $\begin{array}{r}\text { 3. REPORT TYPE AND DATES COVERED } \\
\text { Technical Memorandum }\end{array}$ \\
\hline
\end{tabular}

4. TITLE AND SUBTITLE

The NASA CSTI High Capacity Power Program

5. FUNDING NUMBERS

WU $-590-13-11$

6. AUTHOR(S)

Jerry M. Winter

\section{PERFORMING ORGANIZATION NAME(S) AND ADDRESS(ES)}

8. PERFORMING ORgANIZATION

National Aeronautics and Space Administration

Lewis Research Center

Cleveland, Ohio $44135-3191$

\section{REPORT NUMBER}

E- 6567

9. SPONSORING/MONITORING AGENCY NAMES(S) AND ADDRESS(ES)

10. SPONSORING/MONITORING AGENCY REPORT NUMBER

National Aeronautics and Space Administration

Washington, D.C. 20546-0001

NASA TM -105240

AIAA - 91 - 3629

11. SUPPLEMENTARY NOTES

Prepared for the Conference on Advanced Space Exploration Initiative Technologies cosponsored by AIAA, NASA, and OAI, Cleveland, Ohio, September 4-6, 1991. Responsible person, Jerry M. Winter, (216) 433 - 6133.

12a. DISTRIBUTION/AVAILABILITY STATEMENT

12b. DISTRIBUTION CODE

Unclassified - Unlimited

Subject Category 44

13. ABSTRACT (Maximum 200 words)

The SP-100 program was established in 1983 by DOD, DOE, and NASA as a joint program to develop the technology necessary for space nuclear power systems for military and civil applications. During 1986 and 1987, the NASA Advanced Technology Program was responsible for maintaining the momentum of promising technology advancement efforts started during Phase I of SP-100 and to strengthen, in key areas, the chances for successful development and growth capability of space nuclear reactor power systems for future space applications. In 1988, the NASA Advanced Technology Program was incorporated into NASA's new Civil Space Technology Initiative (CSTI). The CSTI program was established to provide the foundation for technology development in automation and robotics, information, propulsion, and power. The CSTI High Capacity Power Program builds on the technology efforts of the SP-100 program, incorporates the previous NASA advanced technology project, and provides a bridge to the NASA exploration technology programs. The elements of CSTI high capacity power development include conversion systems-Stirling and thermoelectric, thermal management, power management, system diagnostics, and environmental interactions. Technology advancement in all areas, including materials, is required to provide the growth capability, high reliability and 7 to 10 year lifetime demanded for future space nuclear power systems. The overall program will develop and demonstrate the technology base required to provide a wide range of modular power systems while minimizing the impact of day/ night operation as well as attitudes and distance from the Sun. Significant accomplishments in all of the program elements will be discussed, along with revised goals and project timelines recently developed.

\section{SUBJECT TERMS}

Power converters; Thermoelectric materials; Radiators; Optical fibers; Space environment simulation; Stirling engines

\begin{tabular}{|l|c|}
\hline $\begin{array}{l}\text { 17. SECURITY CLASSIFICATION } \\
\text { OF REPORT }\end{array}$ & $\begin{array}{c}\text { 18. SECURITY CLASSIFICATION } \\
\text { OF THIS PAGE } \\
\text { Unclassified }\end{array}$ \\
\begin{tabular}{l} 
Unclassified \\
\hline
\end{tabular}
\end{tabular}

19. SECURITY CLASSIFICATION OF ABSTRACT Unclassified 
National Aeronautics and Space Administration

Lewis Research Center

Cleveland, Ohio 44135

Official Business

Penalty for Private Use $\$ 300$
FOURTH CLASS MAIL

ADDRESS CORRECTION REQUESTED
|||||

Postage and Fees Pars

National Aeronautics and

Space Administration

NASA 451 